\title{
Severe combined immunodeficiency due to LCK deficiency
}

INSERM

\section{Source}

INSERM. (1999). Orphanet: an online rare disease and orphan drug data base. Severe combined immunodeficiency due to LCK deficiency. ORPHA:280142

A rare, combined T- and B-cell immunodeficiency characterized by failure to thrive, severe diarrhea, opportunistic infections, and abnormal T-cell differentiation and function due to LCK deficiency, leading to an important risk factor for inflammation and autoimmunity. 